\title{
Christianity, the Free Market, and Libertarianism
}

Christian Light

Joseph A. Butt, S.J. College of Business, Loyola University New Orleans, the United States of America

e-mail: cllight@loyno.edu

Walter E. Block

Harold E. Wirth Eminent Scholar Endowed,

Chair and Professor of Economics

Joseph A. Butt, S.J. College of Business, Loyola University New Orleans, the United States of America

e-mail:wblock@loyno.edu

\begin{abstract}
:
In recent centuries Christians of various denominations have endorsed many different political philosophies that they see as being truly biblical in their approach. Over this time there has been an increasing hostility, by some Christians, towards free markets and political philosophies that hold human liberty as the highest goal such as libertarianism and classical liberalism. This criticism is unwarranted and misplaced as libertarianism and free markets are not only compatible with Christianity, they are also the most biblically sound of all economics systems and political philosophies endorsed by Christians today. Therefore, this paper will argue that Christians of all denominations should endorse free markets and libertarianism if they wish to create a world that follows biblical principles and the teachings of Jesus.

Keywords: Christianity, free enterprise, libertarianism.
\end{abstract}




\section{Introduction}

Since Karl Marx began writing criticism of what he called "capitalism" and subsequently invented his own economic system known as "communism" the free market system has come under more and more scrutiny and hostility. This includes even some elements of Christianity. Catholic social teaching in the last century has become more critical of markets and as a result has been friendlier to government regulation and intervention into the market. What makes this an interesting phenomenon is that some of the earliest work by Catholic thinkers on economics, notably the Spanish Scholastics, ${ }^{1}$ was strongly supportive of free markets. Not all elements of Christianity are as critical to the market as the Catholic Church has become over the last century. ${ }^{2}$ Many Christians who would identify on the "Christian right" in America are perhaps at least semi-sympathetic to the market economy. However, even most of these Christians are ignorant or misguided regarding basic elements of economics. ${ }^{3}$ Most still favor some sort of government intervention and regulation of the market but just not as much as their Catholic brothers. There has also been an increasing hostility by Christians toward political philosophies such as libertarianism that endorse the free market. ${ }^{4}$ This criticism is unwarranted as, the theme of the present paper, free markets and libertarianism are completely compatible with Christianity. Many elements of Christian thought are found in free markets and libertarianism and it is for this reason that Christians should support free markets and political philosophies such as libertarianism and classical liberalism.

In section 2 we discuss the early scholastics. Section 3 is given over to an analysis of private property. In section 4 we discuss rendering unto Caesar. The burden of section 5 is our claim that Jesus was an anarchist. The Prince of Peace is the focus of section 6. We conclude in section 7.

\section{The Early Scholastics}

Early Catholic thinkers on economics were not always as hostile toward the market as their catholic successors in the modern era. In fact, with the rediscovery of many of the works of the Spanish Scholastics many of them could be considered friendlier to the free market than even some modern economists who claim to favor the free market. According to Tom Woods (2002):

Much of what these sixteenth-century Catholic thinkers taught in the economic realm revealed a considerable understand of and appreciation for the functioning of the market, including the role of entrepreneurship, the nature of exchange, and the justice of prices and wages determined by the free interplay of supply and demand.

The Spanish Scholastics were indeed ahead of their time compared to even some later economists in the seventeenth and eighteenth centuries. ${ }^{5}$ However, they were not perfect and lacked a method in their approach as "They were, moreover, interested more in the moral dimension of economics than in a descriptive elaboration of how various economic mechanisms functioned" (Woods, 2002).

The areas where the Spanish Scholastics excelled in economic thought were wages and prices. The Spanish Scholastic Juan de Mariana had strong words for those that would interfere with prices in the market:

Only a fool would try to separate these values in such a way that the legal price should differ from the natural. Foolish, nay, wicked the ruler who orders that a thing the common people value, let us say, at five should be sold for ten. Men are guided in this matter by common estimation founded on considerations of the quality of things, and their abundance or scarcity. It would be vain for a Prince to seek to undermine these principles of commerce. 'This best to leave them intact instead of assailing them by force to the public detriment' (Woods, 2002). 
Even in the sixteenth and seventeenth century it was obvious to the Spanish Scholastics that state intervention in free markets, such as price controls, price floors, and price ceilings, was futile in nature and would always end up causing more damage and distorting the market more than helping it. At the time there was much debate of what the "just price" on the market was to be. The Spanish Scholastics demonstrated that "the just price was the market price, the price established by the "common estimation' of buyers and sellers" (Woods, 2002). Although these economists, mainly Jesuit ${ }^{6}$ and Dominican priests lacked the knowledge of subjective value theory it was obvious to them that scarcity and supply and demand properly and morally influenced how prices arose on the free market.

The Spanish Scholastics also made progress in their analysis of wages. The Spanish Scholastics' theory of prices had direct relation to their theory on wages in that "the just wage was that which was reached by means of the common estimation of the market" (Woods, 2002). In regards to wages the Spanish Scholastic Luis de Molina:

... taught that the owner was 'only obliged to pay [the laborer] the just wage for his services considering all the attendant circumstances, not what is sufficient for his sustenance and much less the maintenance of his children and family.' Domingo de Soto stated the matter even more concisely, concluding that 'if they freely accepted this salary for their job, it must be just.' $\mathrm{He}$ held that 'no injury is done to those who gave their consent,' and suggested to the laborers '[I]f you do not want to serve for that salary, leave!' (Woods, 2002).

This viewpoint has been severely criticized by Catholic social thought in the modern era. The Catholic Bishops of several countries have issued letters on the economy that call for massive interferences in labor markets. ${ }^{7}$ Today it is a commonly held view by economists that wages tend to equal worker productivity. However, despite lack of knowledge of a worker productivity theory of wages, the Spanish Scholastics were able to discover that all prices on the market, including wages, come to be because of the problem of scarcity and supply and demand. One wonders, too, how the 16th century Jesuits and Domincans of this School would have assessed the economic work of those bishops who came long after them. Not too highly.

Modern Catholic social thought conflicts with quite a bit of what the early Scholastics espoused. The general attitude of modern Catholic social thought is hostility to the market. According to Tom Woods (2002)

... the popes have consistently rejected the Marxist position...But having said that , they go on in their various critiques of the market to suggest, even if usually only implicitly, that all is disorder and chaos and that intervention by public authority is indispensable for obtaining justice in the economic realm.

Some Catholic social thinkers, such as John A. Ryan (1906, 1916, 1919, 1923) and Heinrich Pesch (1900, 1905 - 1923), dismiss the idea of economic law altogether. According to Woods (2002 among Catholic social thinkers "the concept of economic law, when it is mentioned at all, is generally ridiculed and dismissed as a rationalization of greed." In addition, Ryan also "rejects the idea that wage determination has anything to do with worker productivity, which he argues is impossible to measure" (Woods, 2002). Ryan (1906) is a believer in a "living wage" and even wrote a book on the subject with that title. The problem, here, of course, is the if this "living wage" is greater than the productivity of the worker, he will be unemployed, something, presumably, not sought by the forces of social "justice." More recent papal encyclicals have gone beyond the argument for a living wage by endorsing additional benefits for workers. The papal encyclical Laborem Exercens (John Paul, 1981) states "The expenses involved in health care, especially in the case of accidents at work, demand that medical assistance should be easily available for workers, and that as far as possible it should be cheap or even 
free of charge." The encyclical goes further in advocating a "right to rest" and pensions and insurance to employees. But, the higher the wage, whether in salary or in this case in terms of fringe benefits, the more unemployment ensues. The thought of the Spanish Scholastics contrasts with much of what modern Catholic social thought endorses. We go further: these older scholars are now spinning in their graves at the deterioration of economic knowledge that has occurred in this sector of intelligencia.

The Spanish Scholastics saw economic laws in action while most modern Catholic social thinkers try to deny them completely. These earlier scholars declared that the "just wage" is the "market wage" and that if an employee agrees to work for a certain wage and benefits, on his own free will and without being coerced, then it is just. Modern Catholic social thinkers believe that most laborers are under compensated and deserve not only a "living wage" but that if the employer doesn't provide certain benefits in addition to the wage he is unjust. Such talk is nonsense of course. Economic law exists with just as much validity as laws in any other branch of science. To deny them is to deny reality. The fact that so many modern Catholic social thinkers deny or ridicule the laws of economics is even more disappointing in light of this statement by Woods (2002) that "One of the characteristic features of Catholic thought over the centuries has been its emphasis on reason." If Catholic social thinkers would like to make progress in their views regarding economics it would be wise of them to once again bring this characteristic back into their economics analysis.

\section{Private Property}

The seventh commandment is the starting point for understanding how Christianity and private property intertwine. This commandment states "You shall not steal" (Exodus 20:15, New International Version). This is not necessarily an explicit recognition of private property but at least an implicit one. Private property rights are logically entailed by this commandment. If no one owned anything then the concept of stealing could not even exist. There could be no such thing as stealing without the existence of of private property. The seventh commandment demonstrates that God does not see private property as an inherent evil as socialists and communists would have it. This commandment shows that God believes the private property of others should be respected and essential for doing so is to not take it away from them without their consent. The Reverend Larry Beane (2014), a Lutheran minister, has this to say about the seventh commandment and private property:

The seventh commandment is: 'You shall not steal' (Ex 20:15). This is the basis for capitalism. Without the seventh commandment, there is no civilization, but only barbarism, the law of the jungle, and the ethical principle of 'might makes right.' By contrast, God's Law recognizes private property as not only a nice thing, but a commandment to be obeyed. Respect for private property lays down the capitalist economic system. No other system respects the seventh commandment.

"By divine revelation, private property is a given, and it follows that non-aggression against that private property is God's Law. And by definition, property can be freely used by the owner in whatever way he does not aggress against his neighbor. As we would like to maintain our own property, so we should do unto others (Luke 6:31). The seventh commandment is the basis of the rule of law at home and of treaties abroad, of respected borders and is manifested in Scripture by stone markers laying out property lines (e.g. Prov 22:28). It is the foundation of trade, in which property-owners barter with one another, or use a common medium of exchange (money) to affect mutually-beneficial transactions.

Understanding the seventh commandment and private property is important to appreciating why Christianity and free markets are compatible. 
Since the first encyclical concerning economics, Rerum Novarum, was written in the late eighteen hundreds the Catholic Church has been relatively consistent on the issue of private property. This encyclical explicitly denounces socialism and says of the socialists that "They are, moreover, emphatically unjust, for they would rob the lawful possessor, distort the functions of the State, and create utter confusion in the community" (Pope Leo XIII, 1891, par. 4). The encyclical goes on to say that "every man has by nature the right to possess property as his own" (Pope Leo XIII, 1891, par. 6). It is refreshing to see the Catholic Church take a decisive stand on an important issue that was of great debate during the late eighteen hundreds when socialism, communism, and Marxism were gaining in popularity. However, the papal encyclicals can be conflicting on some issues regarding private property such as one which states "Goods can be transferred to the public domain only by the competent authority, according to the demands and within the limits of the common good, and with fair compensation" (Pope Paul VI, 1965, para. 71). Although the last statement contains very ambiguous phrases, such as "competent authority," "common good," and "fair compensation," it should not be overlooked that the Catholic Church has at least taken a hardline stance defending private property. Private property is indispensable for the functioning of a free market economy. The protection of private property under the seventh commandment shows that, at least regarding the issue of private property, Christianity and the free market are compatible with each other. And, as private property rights are virtually the bedrock principle of libertarianism, this demonstrates an even more profound link between the two.

\section{Render Unto Caesar}

In a well-known Bible passage Jesus is quoted as saying "Render therefore unto Caesar the things which are Caesar's; and unto God the things that are God's" (Matthew 22:21, King James Bible). This passage has been used by many Christians and clergymen to justify the state and its legitimacy. However, closer examination of this passage is necessary to understand the true context. It is said in the passage immediately before this that "the Pharisees went out and laid plans to trap him in his words" (Matthew 22:15, New International Version). They then ask Jesus "is it right to pay taxes to Caesar or not? (Matthew 22:17, New International Version). In asking Jesus this question the Pharisees were trying to trick him. If he answered It is right to pay taxes to Caesar the Pharisees could criticize Jesus for upholding Caesar's law over the Jewish (Godly) law. If Jesus was to answer that it was not right to pay taxes to Caesar they could also trap him and accuse him of being a traitor to the Roman Empire and to Caesar himself. In this way Jesus' answer to the question seems vague but also keeps him from falling into the clutches of the Pharisees.

When one analyzes the passage closer it can be seen that his reply is almost a joke of sorts. Jesus says "Render therefore unto Caesar the things which are Caesar's" but what things does Caesar deserve to have rendered to him? The answer is, obviously, nothing. Caesar does not deserve anything rendered unto him as he is a tyrant who caused much grief for the Jewish people at the time. ${ }^{8}$ Now consider the last part of the passage. Jesus says "and unto God the things that are God's." What things does God deserve compared to Caesar? Coming from a Judeo-Christian point of view it is obvious that God deserves the exact opposite to nothing, that is, everything. God is the creator of everything and therefore deserves all things whether they are material or spiritual. Caesar deserves nothing. He is a tyrant and has not only given the Jewish people nothing. Not only has Caesar not given the Jewish people anything he has taken much away from them through violence and thus made them worse off; far worse off. Caesar does not deserve any taxes that are rendered unto him.

The passage ends saying that "When they heard this, they were amazed. So they left Him and went away" (Matthew 22:22, New International Version). The answer Jesus gave was perfect. He answered their question while not explicitly nor even implicitly taking one side or the other. The 
Pharisees, not expecting such a cunning answer to their challenge, thus had no reply. Contrary to claims that this passage supports the state and its doings the very opposite is the case.

\section{Jesus Was an Anarchist}

The role of Jesus was to deal with spirituality and not necessarily with earthly matters. Stated this way it seems troublesome to even try and reconcile any one economic system or political philosophy as being the "right one in the eyes of God". The Catholic Church does not endorse one political or economic ideology. As long as an economic system or political philosophy does not violate the beliefs of Christianity then it can be seen as acceptable in the eyes of a Christian and God. However, this means there are legitimate economic systems and political philosophies that Christians can endorse and those that must be abjured.

How does the political philosophy of libertarianism fit in? Although this is not the only political philosophy compatible with biblical teachings, it upholds biblical teachings to a greater degree than any other. Libertarianism essentially comes down to the non-aggression principle which "asserts that 'aggression' is inherently illegitimate. 'Aggression' is defined as the 'initiation' of physical force against persons or property, the threat of such, or fraud upon persons or their property" (Principle of non-agression, 2014). Similarly Jesus says in the Bible "So in everything, do to others what you would have them do to you" (Matthew 7:12, New International Version). This is sometimes known as the "golden rule." After reconciling these two principles it can be seen that Christianity and libertarianism have much in common in regards to how others and their property should be treated. ${ }^{9}$

Libertarianism does not violate biblical principles and is therefore compatible with Christianity. Looking critically at some of the principles Jesus espouses it can be inferred that he was not a big fan of the state. Since Jesus favored non-violence and peace then it follows that no true Christian should support the government. After all the state $\mathrm{z}$ is nothing but violence writ large (Rothbard, 1963). Taxes are theft and war is murder. The fact that the state gives these immoral actions a different name does not make them any less immoral. The state clearly violates the commandment regarding murder "You shall not murder" (Exodus 20:13, New International Version) and theft "you shall not steal" (Exodus 20:15, New International Version). If any Christian is to support the government then their biblical and philosophical beliefs will clash. Taking this to its logical conclusion, Jesus could not have espoused any view supporting such an immoral institution as the state. Although He never explicitly states any political philosophy it is implicit; the state violates even the most basic pillars of the Christian faith. Jesus would not have supported the state for any reason since it was founded on these grounds (Rothbard, 1982), and his followers should not support it either.

\section{The Prince of Peace}

In recent years there has been an unfortunate rise in the "Christian Right" of love for war, militarism, the military, and the warfare state in general. This is ironic in itself because Jesus is often given the title "The Prince of Peace." This should be no surprise since He advocated non-violence, peace, and the "golden rule" as principles to which all Christian should adhere. ${ }^{10}$ Those Christians who hold neoconservative beliefs often use their religion, as justification for the wars and militarism they support. Nothing could be a greater distortion of the teachings of Jesus than to turn them into an endorsement of mass murder.

On the issue of war and peace Jesus and libertarians can find much to agree on (Vance, 2008A, 2009, 2012). Libertarianism itself, like Christianity, is not strictly pacifistic in nature. In fact very few libertarians are pacifists; most hold the right to self-defense in high regard. The non-aggression principle (NAP) states that it is only illegitimate to initiate force. Thus retaliatory force is legitimate. 
The same is similar with Christianity. A devout Christian is not expected to be pacifist in nature, although some Christians do hold that view. Based upon the Bible, however, it would seem that Jesus was a pacifist. ${ }^{11}$ The imperialistic use of force that those on the "Christian right" endorse is illegitimate. It is sad that many of these Christian conservatives have been tricked into believing that the state, the military, and constant warfare are somehow compatible with their religion that teaches peace and nonviolence. If only these Christians could incorporate what the great Austrian economist Ludwig von Mises (2009, p. 59) meant when he said "War is harmful, not only to the conquered but to the conqueror. Society has arisen out of the work of peace; the essence of society is peacemaking. Peace and not war is the father of all things ... Peace builds, war destroys." Libertarianism is a political philosophy that teaches peace and non-violence. The NAP world that libertarians envision is very similar to the Christian one. This is a world where peace and non-initiatory violence are respected by everyone.

\section{Conclusion}

All arguments claiming Christianity, private property rights and free markets are not compatible are either internally flawed or misrepresent libertarianism. These different institutions overlap in many different areas. The early Spanish Scholastics favored the free market and saw its compatibility with the teachings of Jesus and the Bible. Christianity and libertarianism both recognize and hold private property in high regard. A free market is predicated upon private property rights. Many different sayings and parables by Jesus have been used by Christians to justify their opinion that He favors the state. These arguments are mistaken. The only true political system from a Christian point of view is a "voluntary" state or anarchism. Finally, the recent rise of the Christian right and its fondness of the military and the warfare state is contrary to the teachings of Jesus. His precepts and the political philosophy of libertarianism are eminently compatible.

\section{References}

1. Ahiakpor, J. C. W. Rashid on Adam Smith: In Need of Proof, The Journal of Libertarian Studies, Vol. 10, No. 2, Fall, 1992, pp. 171-180.

2. Ahiakpor, J. C. W. Did Adam Smith Retard the Development of Economic Analysis? A Critique of Murray Rothbard's Interpretation, The Independent Review 3, No. 3 (Winter) 1999, pp. 355-83.

3. Ahiakpor, J. C. W. On Aspromourgos's Mistaken Reading of Adam Smith's Price Theory, History of Economic Ideas 16, No. 3 (Summer), 2008,pp. 119-24.

4. Barnett, W. Human Nature, the Bishops, and the American Economy, 33 Loyola Law Review 203, 1987-1988.

5. Beane, L. Capitalism is the Only Divinely-Sanctioned Economic System, 2014, Retrieved from: http://fatherhollywood.blogspot.com/2014/05/capitalism-is-only-divinely-sanctioned.html.

6. Benedict, Pope. 2009,Love in Truth;

http://www.vatican.va/holy_father/benedict_xvi/encyclicals/documents/hf_ben-

xvi_enc_20090629_caritas-in-veritate_en.html

7. Block, W. Focus on Economics and the Canadian Bishops, Vancouver: The Fraser Institute, 1983.

8. Block, W. E. Neglect of the Marketplace: The Questionable Economics of America's Bishops, Notre Dame Journal of Law, Ethics and Public Policy, Vol. 2, No. 1, 1985a, pp. 125-160.

9. Block, W. E. Liberation Theology and the Economy, Grail: An Ecumenical Journal, Vol. I, No. 3, September, 1985b, pp. 75-85.

10. Block, W. E. The U.S. Bishops and Their Critics: An Economic and Ethical Perspective, Vancouver: The Fraser Institute, 1986. 
11. Block, W. E. Economics of the Canadian Bishops, Contemporary Policy Issues, Vol. VI, No. 1, January, 1988, pp. 56-68.

12. Block, W. E. Religion and Libertarianism: Ayn Rand was wrong, June 18, 2008.

13. Block, W. E. Religion and libertarianism, July 7, 2012.

14. Block, W. E. and Yeatts, G. The Economics and Ethics of Land Reform: A Critique of the Pontifical Council for Justice and Peace's 'Toward a Better Distribution of Land: The Challenge of Agrarian Reform,' Journal of Natural Resources and Environmental Law, Vol. 15, No. 1, 1999-2000, pp. 37-69.

15. Booth, P. (ed.). Catholic social teaching and the market economy, London: Institute of Economic Affairs, 2007.

16. Carden, A. Christian Ethics, Formal Institutions, and Economic Growth, American Review of Political Economy, 5(1), 2007, pp. 34-53.

17. Chafuen, A. A. Christians for Freedom: Late Scholastic Economics, San Francisco: Ignatius Press, 1986.

18. Chafuen, A. A. Faith and Liberty: The Economic Thought of the Late Scholastics, Studies in Ethics and Economics, Lanham: Lexington, 2003.

19. Epstein, M., Block, W. E. and, Woods Jr. T. Chesterton and Belloc: A Critique, Independent Review, Vol. 11, No. 4, 2007, pp. 579-594.

20. Francis, Pope. Praise Be to You - Laudato Si': On Care for Our Common Home; http://w2.vatican.va/content/francesco/en/encyclicals/documents/papa-francesco_20150524_enciclicalaudato-si.html

21. Gasaway, B. W. Progressive Evangelicals and the pursuit of social justice, The University of North Carolina Press, 2014.

22. Grice-Hutichinson, M. The School of Salamanca, Oxford: Oxford University Press, 1952.

23. Hananoki, E. Mike Huckabee's 'Leftwing Argument Against Capitalism', January 12, 2012; http://mediamatters.org/blog/2012/01/12/mike-huckabees-leftwing-argument-against-capita/186134.

24. Heyne, P. The U.S. Catholic Bishops and the Pursuit of Justice, Cato Policy Analysis, No. 50, March1985.

25. Huerta de Soto, J. New Light on the Prehistory of the Theory of Banking and the School of Salamanca, The Review of Austrian Economics, Vol. 9, No. 2, 1996, pp. 59-81.

26. Huerta de Soto, J. Juan De Mariana: The Influence of the Spanish Scholastics,2004; https://www.scribd.com/document/328171967/Juan-de-Mariana-the-Influence-of-the-Spanish-

$\underline{\text { Scholastics }}$

27. Huerta de Soto, J. Biography of Juan de Mariana: The Influence of the Spanish Scholastics (1536-1624), August 1, 2007; https://mises.org/library/biography-juan-de-mariana-influence-spanishscholastics-1536-1624

28. Huerta de Soto, J. Juan de Mariana and the Spanish Scholastics, 2017; http://www.jesushuertadesoto.com/articles/articles-in-english/juan-de-mariana-and-the-spanish

scholastics/

29. Ianelli, J. and Block, W. E. The Moral Resonance of Catholic Globalization Perspectives, Humanomics, Vol. 25, No. 3, 2009, pp. 189-196.

30. John Paul, Pope, Laborem Exercens, 1981, http://www.vatican.va/holy_father/john_paul_ii/encyclicals/documents/hf_jpii_enc_14091981_laborem-exercens_en.html

31. John Paul, Pope. Sollicitudo Rei Socialis, 1987, http://www.vatican.va/holy_father/john_paul_ii/encyclicals/documents/hf_jp-

ii_enc_30121987_sollicitudo-rei-socialis_en.html

32. John Paul, Pope. Centesimus Annus, 1991, 
http://www.vatican.va/holy_father/john_paul_ii/encyclicals/documents/hf_jp-

ii_enc_01051991_centesimus-annus_en.html

33. Leo XIII, Pope. Rerum Novarum, 1891,

http://www.vatican.va/holy_father/leo_xiii/encyclicals/documents/hf_l-xiii_enc_15051891_rerum-

novarum_en.html

34. McElroy, W. Can a Principled Libertarian Go to War? July 6, 2011; https://mises.org/daily/5431/

35. Mises, L. Socialism: An Economic and Sociological Analysis, Auburn: The Ludwig von Mises Institute, 2009.

36. Novak, M. The Spirit of Democratic Capitalism, New York: Simon \& Schuster, 1978.

37. Novak, M. (ed.). The Denigration of Capitalism, Washington, D.C.: American Enterprise Institute for Public Policy, 1979a.

38. Novak, M. (ed.). Capitalism and Socialism, Washington, D.C.: American Institute for Public Policy Research, 1979b.

39. Novak, M. (ed.). Liberation South, Liberation North, Washington, D.C.: American Enterprise Institute for Public Policy, 1981a.

40. Novak, M. (ed.). The Corporation: A Theological Inquiry, Washington D.C.: American Enterprise Institute for Public Policy Research, $1981 b$.

41. Novak, M., George J. Gillespie, Michael Joyce, William E. Simon, Patricia Leeds. Toward the Future: Catholic Social Thought and the U.S. Economy - A Lay Letter, New York: Lay Commission on Catholic Social Teaching and the U.S. Economy, 1984.

42. Novak, M. The Liberal Society as Liberation Theology, Notre Dame Journal of Law, Ethics and Public Policy, Vol. 2, No. 1, 1985a.

43. Novak, Michael. B. "The Two Catholic Letters on the U.S. Economy," in Challenge and Response, Robert Royal, ed., Washington, D.C. Ethics and Public Policy Center, 1985, pp. 30-32.

44. Novak, Michael. "The Bishops and the Poor," Commentary Magazine, May, 1985, pp. 20-22.

45. Novak, M. Will it Liberate? Questions about Liberation Theology, New York: Paulist Press, 1986.

46. Novak, Michael. Boredom, Virtue and Democratic Capitalism, Commentary, Vol. 88, No. 3, 1989.

47. Novak, M. The Catholic Ethic and the Spirit of Capitalism, New York: The Free Press, 1993.

48. Paul VI, Pope. Gaudium et Spes, 1965;

http://www.vatican.va/archive/hist_councils/ii_vatican_council/documents/vat-

ii_cons_19651207_gaudium-et-spes_en.html

49. Paul VI, Pope. Populorum Progressio, 1967;

http://www.vatican.va/holy_father/paul_vi/encyclicals/documents/hf_p-

vi_enc_26031967_populorum_en.html

50. Pesch, H. Lehrbuch der Nationalökonomie (Teaching Guide to Economics), 5 Vol. transl. by R J. Ederer, Lewiston, New York: Edwin Mellen Press, 1905-1923.

51. Pesch, H. Liberalismus, Socialismus und Christliche Gesellschaftsordnung, Vol. 2, Herder, 1900; Liberalism, Socialism and Christian Social Order, transl. by R. J. Ederer, Edwin Mellen Press, 2000.

52. Principle of non-aggression. 2014. Retrieved April 3, 2015 from

http://wiki.mises.org/wiki/Principle_of_non-aggression

53. Ritenour, S. Foundations of Economics: A Christian View. Eugene, Oregon: Wipf and Stock, Publishers, 2010; http://wipfandstock.com/store/Foundations_of_Economics_A_Christian_View http://www.foundationsofeconomics.com

54. Rockwell, Jr., and Llewellyn, H. Free Market Economists: 400 Years Ago, The Freeman: Ideas on Liberty. Vol. 45, No.9, 1995.

55. Rothbard, M. N. War, Peace, and the State, The Standard, April, 1963, pp. 2-5; 15-16. 
http://www.mises.org/rothbard/warpeace.asp

56. Rothbard, M. N. New Light on the Prehistory of the Austrian School, In. E. G. Dolan (ed.), The Foundations of Modern Austrian Economics, Kansas City: Sheed \& Ward, Inc., 1976, pp. 52-74.

57. Rothbard, M. N. The Ethics of Liberty, Atlantic Highlands: Humanities Press, 1982.

58. Rothbard, M. N. Adam Smith Reconsidered, Austrian Economics Newsletter, Auburn, AL: The Ludwig von Mises Institute, 1987, pp. 5-7. Reprinted in Austrian Economics (Vol. 1) by S. Littlechild, Brookfield, VT: Edward Elgar Publishing Company, 1990, pp. 41-44.

59. Rothbard, M. N. Just War, In. J. V. Denson, (ed.), The Costs of War: America's Pyrrhic Victories, New Brunswick, N.J.: Transaction Publishers, 1997.

60. Rothbard, M. N. Economic Thought before Adam Smith: An Austrian Perspective on the History of Economics Thought, Vol. 1, Cheltenham Glos: Edward Elgar, 1995.

61. Ryan, J. A. A Living Wage: Its Ethical and Economic Aspects, New York: Macmillan Co., 1906.

62. Ryan, J. A. Distributive Justice: The Right and Wrong of Our Present Distribution of Wealth, New York: Macmillan Co., 1916.

63. Ryan, J. A. The Church and Socialism and Other Essays, Washington: The University Press, 1919.

64. Ryan, J. A. The Supreme Court and the Minimum Wage, New York: Paulist Press, 1923.

65. Sider, R. J. Rich Christians in an age of hunger; moving from affluence to generosity, Nashville, TN: Thomas Nelson, 2005.

66. Sider, R. J. Just Generosity, Grand Rapids, Michigan: Baker Books, 2007.

67. Sirico, R. A. Moral Base for Liberty, Irvington-on-Hudson, N.Y.: Foundation for Economic Education, 1996.

68. Sirico, R. A. Capitalism, Morality and Markets, London: Institute for Economic Affairs, 2001.

69. Vance, L. M. Book review of How Capitalism Saved America: The Untold History of our Country, the Pilgrims to the Present, (New York: Crown Forum, 2004), The Quarterly Journal of Austrian Economics, Vol. 8, No. 1, 2005, pp. 81-86.

70. Vance, L. M. An Open Letter to the Protestant Community in Behalf of Ron Paul, November 14, 2007; http://www.lewrockwell.com/vance/vance127.html

71. Vance, L. M. Christianity and War and Other Essays Against the Warfare State, Pensacola Florida: Vance Publications, 2nd edition, 2008a.

72. Vance, L. M. The Myth of the Just Price, March 31, 2008b; http://mises.org/daily/2918

73. Vance, L. M. Rethinking the Good War, September 2, 2009; http://www.lewrockwell.com/vance/vance181.html

74. Vance, L. Is Libertarianism Compatible With Religion? March 15, 2011;

http://libertarianchristians.com/2011/03/16/is-libertarianism-compatible-with-religion/

75. Vance, L. M. My Antiwar Odyssey, August 22, 2012;

http://www.lewrockwell.com/2012/08/laurence-m-vance/my-antiwar-odyssey/

76. Watner, Carl. 'All Mankind is One': The Libertarian Tradition in Sixteenth Century Spain,The Journal of Libertarian Studies, Vol. 8, No. 2, 1987, pp. 293-310.

77. Williams, W. E. Good Intentions - Bad Results: The Economic Pastoral and America's Disadvantaged, Notre Dame Journal of Law, Ethics and Public Policy, Vol. 2, Issue No. 1, 1985, pp. 179-199.

78. Woods Jr., T. Catholic Social Teaching and Economics Law: An Unresolved Tension, March,2002; http://archive.lewrockwell.com/woods/woods8.html

79. Woods, Jr., T. E. Morality and Economic Law: Toward a Reconciliation, 2004; http://www.mises.org/fullstory.asp?control=1481

80. Woods, T. E. Jr. The Church and the Market: A Catholic Defense of the Free Economy, Lanham, Md.: Rowman and Littlefield, 2005. 
81. Woods, T. An Open Letter to the Catholic Community in Behalf of Ron Paul, November 21, 2007; http://www.lewrockwell.com/woods/woods83.html

82. Woods, Jr., T. E. The Attractiveness of Austrian Economics, July 21, 2013;

https://www.youtube.com/watch?v=DStLhWMRERM

\section{Notes}

1. The Spanish Scholastics were a group of economists, precursors to the Austrian School of economics, who favored free enterprise, profits,private property and the rule of law. The Catholic orders most highly represented in this school of economics were the Jesuits and the Dominicans. The main Dominicans included: Francisco de Vitoria, 1485 - 1546; Domingo de Soto, 1494 - 1560; Juan de Medina, 1490 - 1546; Martin de Azpilcueta (Navarrus), 1493 - 1586; Diego de Covarrubias y Leiva, 1512 - 1577; Tomas de Mercado, 1530 - 1576. The most important contributors from the Jesuit order were: Luis Molina (Molineus), 1535 - 1600; Cardinal Juan de Lugo, 1583 - 1660; Leonard de Leys (Lessius), 1554 - 1623; Juan de Mariana, 1536 - 1624. The dates of the main contributions of the Spanish Scholastics were from the early 16th to the 17th centuries. This was entirely a Catholic enterprise, since Protestantism did not arise until a century and more later. This school of thought is sometimes known as the School of Salamanca, since most of its adherents were located in Salamanca, Spain. States Rockwell (1995) of the School of Salamanca: "Vitoria, Navarrus, Covarrubias, and Molina were four of the most important among more than a dozen extraordinary thinkers who had solved difficult economic problems long before the classical period."For more on this see: Booth, 2007; Carden, 2007; Chafuen, 1986, 2003; GriceHutichinson, 1952; Huerta de Soto, 1996, 2004, 2007, 2017; Ritenour, 2010; Rockwell, 1995; Rothbard, 1976, 1995 (pp. 97-133); Sirico, 1996, 2001; Vance, 2011; Watner, 1987; Woods, 2002, 2004, 2005, 2013.

2. See these Papal Encyclicals: Leo, 1891; Paul, 1965, 1967, 1981; John Paul, 1987, 1991; Benedict, 2009; Francis, 2015.On the other hand, non-Catholic Christians have not been exactly behind hand in criticizing the free enterprise system. See on this Gasaway, 2014; Sider, 2005, 2007.

3. For example, Mike Huckabee is associated with this community, and is not exactly known as an advocate of laissez faire capitalism (Hananoki, 2012).

4. For an antidote to this viewpoint, see Woods, 2002, 2005, 2007; Vance, 2005, 2007, 2008A, 2008B, 2009, 2011, 2012; Novak, 1978, 1979A, 1979B, 1981A, 1981B, 1984, 1985A, 1985B, 1985C, 1986, 1989, 1993; Sirico, 2001.

5. For example, see Rothbard's (1987) devastating critique of Smith (1776) for being insufficiently supportive of free enterprise. For a defense of Smith see Ahiakpor (1992, 1999, 2008).

6. The modern Jesuits, with but a few honorable exceptions, support "social justice" a doctrine 180 degrees removed from their predecessors. One wonders what they would have thought of Francis (2015). Presumably, not too highly.

7. For critical reactions, see Barnett, 1987-1988; Block, 1983, 1985A, 1985B 1986; Heyne, 1985; Novak, 1985B, 1985C; Williams, 1985.

8. One of the authors of this essay is of Jewish descent, but is now a devout atheist. He interprets these passages in a poetic or metaphorical manner, and, as such, warmly supports them.

9. The non-aggression principle (NAP) is in some ways preferable to the Golden Rule. For, in the hands of the masochist, initiatory violence could be justified. The masochist says, in effect, "beat me." But, according to the gold Rule, we are to deal with others in the manner we would like to be treated. If so, then the masochist, and only him, would be justified in going around beating people up against the will of the latter.

10. Congressman Ron Paul was vociferously booed and hissed at in the Republican debate in South Carolina in the run up to the 2012 election for saying that the Golden Rule ought be applied to U.S. foreign policy. See https://www.youtube.com/watch?v=HGpXHYtkOS8

11. The Christian doctrine of "just war" is roughly congruent with this libertarian insight. On this see McElroy, 2011; Rothbard, 1997; Vance, 2008. 